\title{
Soil testing for $P$ and $K$ has value in nutrient management for annual crops
}

by Daniel Geisseler and Gene Miyao

\begin{abstract}
Adequate nutrients in forms available to plant roots are essential for sustainable crop production. Soil testing for phosphorus and potassium availability allows growers and crop advisers to determine whether a soil is likely to respond to fertilization. As yields have risen with improved management and production systems, crop nutrient demand and the removal of nutrients with harvested crops have increased. An indepth discussion of soil tests for phosphorus and potassium and their use in California cropping systems is clearly needed. We review how these nutrients become available to plant roots, how samples are taken and test results interpreted, complementary ways to assess the adequacy of supplies and what research is needed to improve soil testing for phosphorus and potassium.
\end{abstract}

$\mathrm{P}$ hosphorus (P) and potassium (K) are essential nutrients required in rather large amounts by crops. The application of fertilizers is often required to meet the crops' demand, with the application rate depending on the availability of nutrients in the soil. Insufficient application rates result in lower yields and may reduce soil fertility over time as the availability of nutrients decreases. In contrast, the application of excess nutrients increases production costs and may cause environmental problems.

Soil testing is one of the most costeffective nutrient management tools

Online: http://dx.doi.org/10.3733/ca.2016a0007 available to growers and crop advisers. It can guide fertilization decisions for individual fields, and it can assess whether a soil is likely to respond to fertilization (Cox 1994). Soils differ in their capacity to supply nutrients to crops.

Early research has shown that many soils in California do not supply sufficient $\mathrm{P}$ to annual crops, and $\mathrm{P}$ fertilization has often been found to be highly beneficial (Jenny et al. 1946). Tree crops, in contrast, are less likely to have a yield response to $\mathrm{P}$ fertilizer. Few cases of $\mathrm{K}$ deficiency were reported in the first half of the 20th century (Jenny et al. 1946). With a few exceptions, $\mathrm{K}$ has not received much attention since then. We focus on $\mathrm{P}$ and $\mathrm{K}$ here, but our discussion applies to other nutrients, such as calcium or magnesium, as well. One exception is soil sampling for residual soil nitrate-N. Nitrate is directly plant available, but much more mobile in the soil than $\mathrm{P}$ and $\mathrm{K}$ and thus easily lost.

An in-depth discussion of soil tests and their use with a focus on California cropping systems is currently missing, but clearly needed. Improved management and varieties have increased productivity considerably in California. Most recently, the shift to semipermanent drip irrigation systems has further increased crop yield. As a result, nutrient removal is higher and soil nutrient depletion faster because of the more confined root zone. A positive response to $\mathrm{P}$ and $\mathrm{K}$ fertilization is now much more likely even on soils that have long been considered sufficiently fertile. For these reasons, and because environmental concerns with overfertilization are being raised more
Soil testing can be used to assess nutrient availability and determine fertilization rates. The foliage damage in this cotton plant was caused by a potassium deficiency. 
frequently, the value of soil testing has increased.

\section{Soil tests as tools}

To be useful, the results of a specific soil test need to be calibrated with the yield response (Mikkelsen 1955). Critical yield response values commonly used in California are given in table 1 for select annual crops. The calibration is done by comparing the yields of a fertilized plot and an unfertilized control. The yield response from many fields is then plotted against the soil test values of those fields, and the soil test values at which a yield response is likely versus unlikely are determined (fig. 1). Based on these results, fertilization recommendations can be developed in rate trials on responsive sites.

For meaningful test results and their correct interpretation, it is important to take a representative sample of the field and to be aware of what soil tests measure and what their limitations are.

\section{Misconceptions about soil tests}

Many growers and crop advisers lack confidence in soil test results - at least partly due to prevailing misconceptions about what information they provide and how it should be interpreted.

For example, soil tests do not represent all pools of nutrients available to crops, which may limit their accuracy in some soil types. Furthermore, soil test values are an index of nutrient availability and cannot be used to calculate the amount of available nutrients in pounds per acre.

Nonetheless, with a good understanding of soil chemistry and laboratory methodology, soil test values can be interpreted correctly for specific fields and cropping systems and can be combined with other tools and approaches to make informed decisions about $\mathrm{P}$ and $\mathrm{K}$ fertilization rates.

\section{Soil P pools and availability}

Phosphorus exists in soil in many different forms, which greatly differ in their plant availability (Fixen and Grove 1990). Plant roots take up $\mathrm{P}$ in the form of phosphate $\left(\mathrm{H}_{2} \mathrm{PO}_{4}^{-}\right.$or $\left.\mathrm{HPO}_{4}{ }^{2-}\right)$ from soil solution. Generally less than 1 pound per acre, or less than $1 \%$ of the total quantity of $\mathrm{P}$

TABLE 1. Soil test interpretation for select annual crops

\begin{tabular}{|c|c|c|c|c|c|}
\hline \multirow[b]{2}{*}{ Crop } & \multicolumn{2}{|c|}{$P$ yield response } & \multicolumn{2}{|c|}{$\mathrm{K}$ yield response } & \multirow[b]{2}{*}{ Source } \\
\hline & Likely & Not likely & Likely & Not likely & \\
\hline & \multicolumn{2}{|c|}{ ppm Olsen P in soil } & \multicolumn{2}{|c|}{$\begin{array}{c}\text { ppmacetate } \\
\text { extractable K in soil }\end{array}$} & \\
\hline Corn & $<6$ & $>12$ & $<50$ & $>80$ & Brown 1976 \\
\hline Cotton & $<3-5$ & $>8$ & $<120$ & $>120$ & $\begin{array}{l}\text { Mikkelsen 1955; Reisenauer et al. } \\
\text { 1978; Weir et al. } 1996\end{array}$ \\
\hline Tomatoes (drip irrigated) & $<10$ & $>20$ & $<200$ & $>300$ & Hartz and Hanson 2009 \\
\hline Wheat & $<6$ & $>12$ & $<40$ & $>60$ & Reisenauer et al. 1976 \\
\hline Barley & $<6$ & $>15$ & $<40$ & $>60$ & $\begin{array}{l}\text { Munier et al. 2006; Reisenauer et } \\
\text { al. } 1976\end{array}$ \\
\hline Sunflower & $<10$ & $>25$ & $<80$ & $>150$ & Shaver et al. 2014 \\
\hline
\end{tabular}

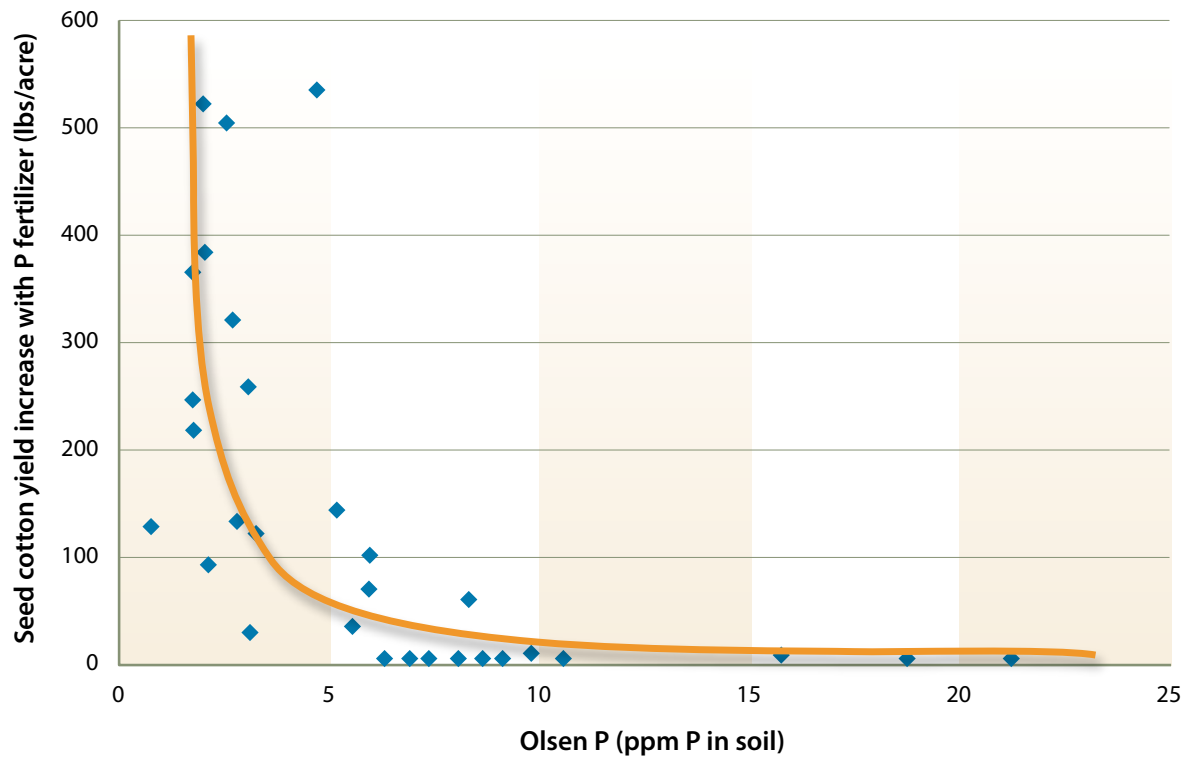

Fig. 1. Example of a field calibration of the Olsen $P$ test for cotton conducted in the San Joaquin Valley. Each dot represents one field trial. The study concluded that a response to $P$ fertilization is likely when the Olsen $\mathrm{P}$ value is below 5.2 parts per million (ppm) and unlikely when the value exceeds $7.8 \mathrm{ppm}$ (redrawn from Mikkelsen 1955).

in the soil, is in soil solution (Pierzynski 1991). Therefore, soil solution P needs to be replenished constantly during the growing season to meet the demand of crops.

Phosphate in soil solution is in equilibrium with phosphate adsorbed to the surface of minerals or bound to cations. Depending on solution P concentrations, reactions with minerals and cations may replenish the solution $\mathrm{P}$ pool or bind solution $\mathrm{P}$. The strength of the interactions between phosphate and minerals varies. Weakly bound $\mathrm{P}$ equilibrates rapidly with the soil solution and replenishes solution P. This pool is often called labile P. Over time, labile bonds may be transformed into stronger bonds resulting in precipitation of low-available P minerals. In contrast, $\mathrm{P}$ may be released from the nonlabile pool and become plant available (Pratt and Lippert 1986).

The primary cations involved in these reactions with phosphate are calcium $\left(\mathrm{Ca}^{2+}\right)$, aluminum $\left(\mathrm{Al}^{3+}\right)$ and iron $\left(\mathrm{Fe}^{3+}\right)$. In neutral and alkaline soils, different forms of Ca-phosphate most strongly determine $\mathrm{P}$ concentration in solution, and thus $\mathrm{P}$ availability. In acidic soils, P solubility is mainly controlled by interactions between phosphate, $\mathrm{Al}$ and Fe ions (Pierzynski et al. 2005). Phosphorus availability is generally highest in slightly acidic soils with a $\mathrm{pH}$ around 6.5 (Stevenson and Cole 1999).

One- to two-thirds of the P in mineral soils is in the organic form (Condron et 
al. 2005; Sharpley 1985). Mineralization of organic P is mediated by soil microorganisms and can significantly contribute to the P nutrition of plants (Oehl et al. 2001). Many different forms of organic $P$ are found in soil, their availability ranging from very labile to highly recalcitrant.

Traditionally, fertilizer application rates have been expressed in units of $\mathrm{P}_{2} \mathrm{O}_{5}$, which is not a form of $\mathrm{P}$ found in soil. Elemental $\mathrm{P}$ is converted to $\mathrm{P}_{2} \mathrm{O}_{5}$ by a multiplication factor of 2.29.

\section{Soil $P$ tests}

Because of the low solubility of major $\mathrm{P}$ forms, the concentration of $\mathrm{P}$ in soil solution is generally low and not a good measure of $\mathrm{P}$ availability. Soil $\mathrm{P}$ tests aim to extract solution $\mathrm{P}$ and the labile inorganic $P$ pool. Due to the complexity of the soil $P$ pools, it is not possible to determine the exact amount of $P$ that will become plant available during the season. Instead, soil tests provide an index of the labile plantavailable $P$ in a soil (Fixen and Grove 1990) by extracting a fraction of the $P$ in the soil that has been found to be correlated with the yield response of crops to $\mathrm{P}$ fertilization (fig. 1). As this fraction is not identical to plant-available $\mathrm{P}$, soil test results cannot be used to calculate the available $P$ in pounds per acre and compare this value with the $\mathrm{P}$ demand of a crop.

The two most commonly used soil tests in California are the Olsen and Bray-P1 tests. Both tests measure solution $\mathrm{P}$ and extract labile fractions of phosphates of $\mathrm{Ca}, \mathrm{Al}$ and $\mathrm{Fe}$. The contribution of these different pools to the P extracted differs due to differences in $\mathrm{pH}$ and chemical composition of the extractant (Beegle 2005).

The Olsen P method uses a sodium bicarbonate solution adjusted to a $\mathrm{pH}$ of 8.5 (Olsen et al. 1954). This test is widely used in soils with a mildly acidic to alkaline pH (Gavlak et al. 2005). The Bray-P1 test uses an acidified ammonium fluoride solution with a $\mathrm{pH}$ of 2.6 to extract $\mathrm{P}$ (Bray and Kurtz 1945). The Bray-P1 soil test is often used in acid to neutral soils (Gavlak et al. 2005).

For both tests, however, the optimal $\mathrm{pH}$ range is soil-specific. Some studies have reported that the Olsen P test performed reasonably well in acidic soils
(John et al. 1967; Smyth and Sanchez 1982). Similarly, in some alkaline soils, the Bray-P1 test is well correlated with the Olsen P test (Ebeling et al. 2008). In California, the Bray-P1 test is generally used in soils with a $\mathrm{pH}$ below 6.0 and the Olsen $\mathrm{P}$ test in soils with a $\mathrm{pH}$ of 6.0 or higher (CPHA 2002).

As these soil tests extract different fractions of the labile $\mathrm{P}$ pool, it is best to use the same test over the years for the same field, so that the results can be compared with the values of previous years. With both tests extracting adsorbed inorganic forms of $\mathrm{P}$, they tend to underestimate $P$ availability in soils with a high soil organic matter content, where the mineralization of organic P may contribute considerably to the available-P pool (Steffens et al. 2010).

\section{Soil K pools and availability}

Plants take up $\mathrm{K}$ in the form of $\mathrm{K}^{+}$from soil solution. Soluble $\mathrm{K}$ is only a small pool that is constantly replenished by exchangeable $\mathrm{K}$ and to some degree by stable, or nonexchangeable, $\mathrm{K}$ (Römheld and Kirkby 2010). Potash $\left(\mathrm{K}_{2} \mathrm{O}\right)$, which is used for fertilizer application rates, is not a form of $\mathrm{K}$ found in soil. Elemental $\mathrm{K}$ is converted to $\mathrm{K}_{2} \mathrm{O}$ by a multiplication factor of 1.2.

Exchangeable $\mathrm{K}$ is held on negatively charged sites of clay minerals and soil organic matter. It is in equilibrium with $\mathrm{K}$ in soil solution, being released when the concentration of $\mathrm{K}$ in solution is low, for example, due to plant uptake (Römheld and Kirkby 2010). The capacity of a soil to exchange $\mathrm{K}$ and other cations such as $\mathrm{Ca}^{2+}$, sodium $\left(\mathrm{Na}^{+}\right)$and magnesium $\left(\mathrm{Mg}^{2+}\right)$ is reflected in its cation exchange capacity (CEC). Solution $\mathrm{K}$ and exchangeable $\mathrm{K}$ represent the available$\mathrm{K}$ pool.

Most $\mathrm{K}$ in soil is present as a component of primary minerals (structural $\mathrm{K})$ or fixed in clay minerals and not immediately available. Available K may be fixed in some soils by clay minerals and thus made unavailable. In California, $\mathrm{K}$ fixation occurs in some soils formed from Sierra Nevada alluvium, located on the east side of the San Joaquin Valley. In contrast, soils formed in Coastal Range alluvium do not fix $\mathrm{K}$, except to a small extent in deeper horizons. In general, K-fixing soils are either weakly developed soils with high mica content or intermediately developed soils with high vermiculite clay mineralogy (Pettygrove and Southard 2003).

As much as $80 \%$ of applied $\mathrm{K}$ can be fixed and become temporarily unavailable to plants (Cassman et al. 1990; Hartz et al. 2002). Nonexchangeable $\mathrm{K}$ becomes only slowly plant available. However, there is no clear boundary between exchangeable and nonexchangeable K (Öborn et al. 2005). Depending on the minerals present and their weathering stage, nonexchangeable K can contribute significantly to plant supply (Kuhlmann and Wehrmann 1984; Öborn et al. 2005; Wang et al. 2011).

Potassium is readily available from crop residues, as it is not incorporated into organic molecules in plant tissue. It can be released from residues even before they decompose.

\section{Soil K tests}

In California, soil $\mathrm{K}$ availability is most often determined from soil samples by extraction with an ammonium acetate solution at neutral pH (Allen et al. 1994). This procedure extracts soil solution $\mathrm{K}$, exchangeable $\mathrm{K}$ and possibly a small proportion of the nonexchangeable pool (Haby et al. 1990). While soil solution K and exchangeable $\mathrm{K}$ can be determined accurately, soil tests may not always extract the fraction of the nonexchangeable $\mathrm{K}$ that becomes crop available (Rengel and Damon 2008; Römheld and Kirkby 2010). Soil tests measuring exchangeable $\mathrm{K}$ are a significantly less precise measure for yield response in K-fixing soil (Cassman et al. 1990; Rees et al. 2013).

\section{Soil test sampling}

One of the most challenging aspects of soil testing is to ensure that the sample taken is representative of the field. A test result from a nonrepresentative sample has little value.

\section{Taking a representative sample}

Most commonly, soil cores are taken from the entire area of the field or management area in a W-shaped sampling pattern or by walking a zigzag course around or through the area (fig. 2). Atypical areas, such as corners or edges of former fields or fencerows that are now in the field, should be excluded (Pennock 
et al. 2008). To capture the variability within fields, it is generally recommended to take 20 to 30 cores from random locations within each field (James and Wells 1990). The composited cores should be thoroughly mixed and submitted for laboratory analysis following instructions of the lab where samples are submitted (Pennock et al. 2008).

Soil test results can vary depending on the time of the year the samples are taken (Childs and Jencks 1967). Samples for $\mathrm{P}$ and $\mathrm{K}$ are best taken in late fall or early spring. They should not be taken when fertilizer has been applied recently. To monitor trends in nutrient availability over the years, it is important to always take samples during the same season and from the same depth. In annual crops, the top 12 inches are generally sampled. Taking samples to the same depth is especially important for $\mathrm{P}$ because $\mathrm{P}$ moves very slowly down the profile due to its immobility in soils (Beegle 2005).

\section{Spatial variability}

Even when care is taken to collect a representative sample, the results of the soil test may still not be very useful when the field is not uniform. When soil properties, past management, plant development or yield history differ within a field, the field should be divided into different management areas with similar characteristics, and a sample from each area should be taken (fig. 2). A convenient way to check for differences in soil properties is to use the interactive application SoilWeb (available at casoilresource.lawr.ucdavis.edu/ soilweb/).

The immobility of $\mathrm{P}$ also means that banded $\mathrm{P}$ can result in fairly long lasting zones of high $P$ test values in no-tillage systems (Beegle 2005). If the location of the band is known, it is generally recommended to take one core from the band for every 20 cores taken. More often than not, the exact location of the bands is not known. In this case, twice as many cores

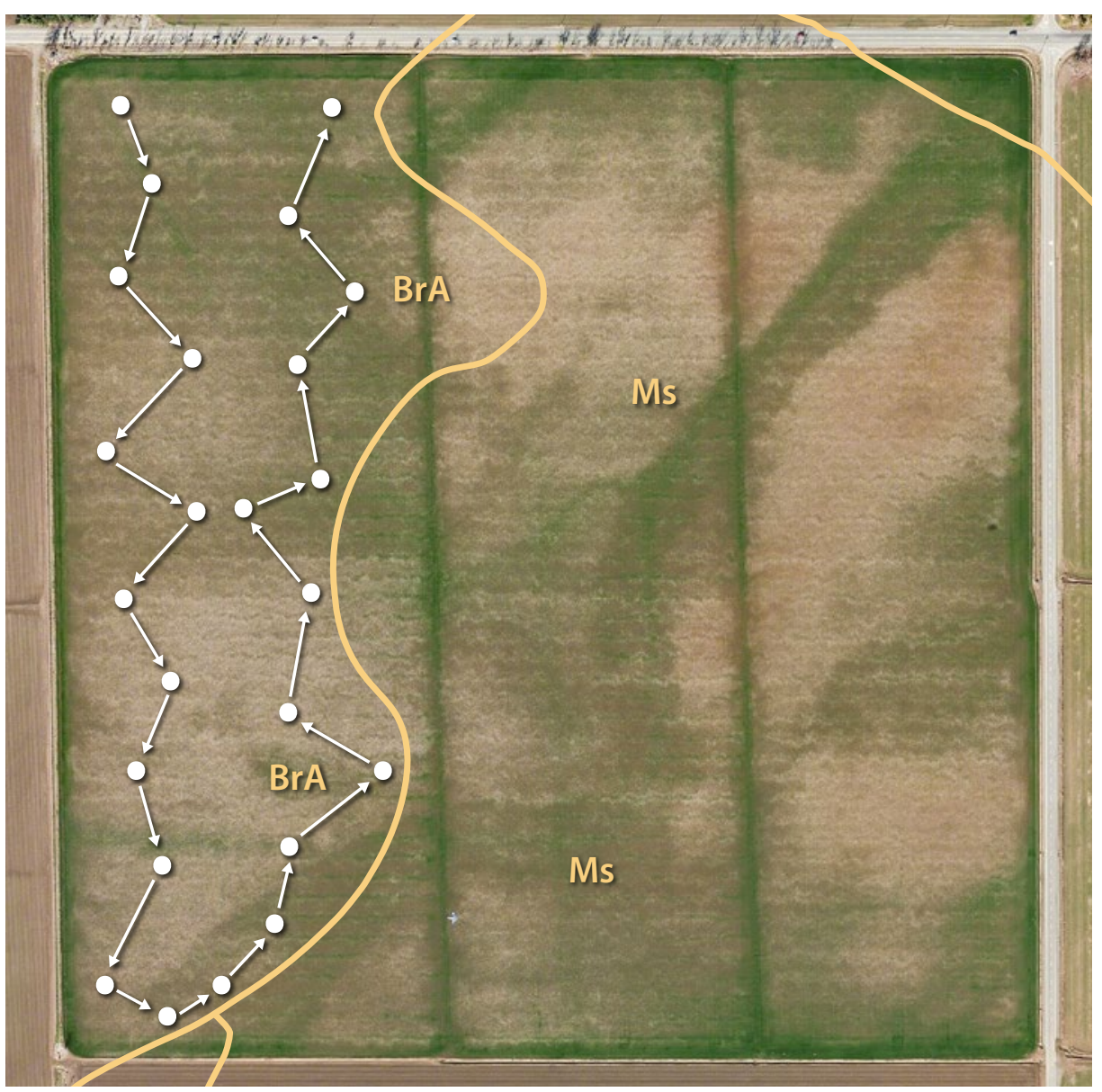

Fig. 2. Soil sampling plan to obtain a representative sample from a field or management area. The sampling points are shown on a Google map using the SoilWeb application (available at casoilresource. lawr.ucdavis.edu/soilweb/). The two soil series, Brentwood silty clay (BrA) and Myers clay (MS), are best sampled separately.

from random locations in the field should be taken compared to the number taken from a field without fertilizer bands.

\section{Sampling drip-irrigated fields}

Some special considerations apply to drip-irrigated fields. With subsurface drip irrigation, the active root zone from which crops draw most nutrients is confined to the region wetted by the drip tape. With the soil volume explored by roots being limited, the potential for a positive response to nutrient application is increased (Hartz et al. 2005; Hartz and Hanson 2009). Therefore, critical soil test values may be higher for drip systems than for furrow-irrigated fields.

Due to the restricted soil volume roots have access to, nutrient concentrations can vary considerably across the bed with distance from the drip line. Depending on the amount of nutrients applied relative to crop uptake and their mobility in soil, nutrients may accumulate or be depleted around the emitters (Carrijo and Hochmuth 2000; Hartz 2008; PalaciosDiaz et al. 2009).

A recent study in drip-irrigated tomato fields found that the variability across the bed can be captured by taking more than one core from the top 20 inches at each sampling location within a field - for example, taking three cores at a distance of 5, 10 and 20 inches from the drip tape in the center of a 60-inch bed (Lazcano et al. 2015). The cores can be pooled for analysis.

\section{Limitations of soil tests}

Soil tests cannot capture all the factors that determine the efficiency with which crops acquire nutrients from the soil, such as crop species, variety and the effects of soil properties on root growth (Cassman, Roberts, et al. 1989; White 2013). For example, rooting depth and root density determine how well a plant can access the pool of potentially available nutrients in the tested layer and in the subsoil (Gahoonia and Nielsen 2004; Richardson et al. 2011; Samal et al. 2010).

Depending on the distribution of nutrients in the soil profile and rooting depth, crops may take up a considerable proportion of nutrients from the soil below the sampled layer. Winter wheat, for example, has been found in one study to acquire $50 \%$ of its $\mathrm{K}$ from the subsoil (Kuhlmann 
and Higashi 2009). In contrast, they do show excess soil $\mathrm{K}$ : vegetative tissue $\mathrm{K}$ concentrations tend to increase in the presence of excess soil $\mathrm{K}$, a process known as luxury consumption (Hawkesford et al. 2012).

\section{Nutrient budgets}

Large amounts of $\mathrm{P}$ and $\mathrm{K}$ can be removed with harvested crops. To maintain adequate nutrient availability over the years, the input of nutrients needs to balance nutrient exports. A nutrient budget, in its simplest form, compares fertilizer inputs with the amount of nutrients removed with harvested crops (output). The nutrient concentrations in harvested plant parts and the amounts of $\mathrm{P}$ and $\mathrm{K}$ removed from the field at harvest are listed in tables 2 and 3 for select annual crops.

Nutrient budgets are less reliable for soils where large losses may occur or for high-fixation soils. In general, losses of $\mathrm{P}$ and $\mathrm{K}$ are minor. There are some exceptions where losses can be significant. Phosphorus is lost from fields with surface runoff or when erosion takes place (Sharpley et al. 2000). Phosphorus leaching losses can be significant in fields with a history of high manure or fertilizer applications, which lead to an accumulation of P in the profile (Brock et al. 2007; Fortune et al. 2005; Hartz and Johnstone 2006; McDowell et al. 2001).

Potassium can be leached in soils with a very low CEC (Wulff et al. 1998). The CEC of a soil mainly depends on its clay content, the dominant clay minerals present and the soil organic matter content. In California, with the exception of very sandy soils with a low soil organic matter content, the CEC is generally sufficient to prevent $\mathrm{K}$ leaching even when large amounts of fertilizer are applied. Potassium may also be leached in very clay-rich soils when cracks are present, allowing $\mathrm{K}$ in soil solution to bypass exchange sites (Alfaro et al. 2004).

\section{On-farm trials}

For some crops, on-farm trials have led to the development of optimal fertilizer application rates based on soil test results (e.g., Miller et al. 1996). On-farm trials give growers the opportunity to evaluate different application rates on a limited area under field- and farm-specific conditions, such as soil types, climate, crop variety and crop management (Hicks et al. 1997).
Based on the results, growers can then decide whether to adopt these rates on part or all of the acreage (Hicks et al. 1997).

Application rates can be tested in small plots or field strips. Field strips are generally more convenient to establish and manage (Hancock 1992). A uniform and representative part of the field needs to be chosen for the trial. The field should not be deficient in other nutrients. Except for the different fertilizer rates, the strips are managed identically. The strips should be large enough so that field equipment can be used for all operations. The strips should also be wide enough to permit harvesting, soil testing and plant tissue sampling from an area that is not affected by the management in the rest of the field (Hancock 1992). For fertilizer trials in row crops, it is generally suggested that the strips be at least two rows wider on each side than the harvested area. When the comparison includes foliar fertilizers, the border area may need to be wider.

The simplest trial includes two treatments, the new application rate and the normal practice, which serves as the control. When the goal of the trial is to determine whether $\mathrm{P}$ and $\mathrm{K}$ fertilization is beneficial, fertilizer is applied to a
TABLE 2. Phosphorus and potassium concentrations in harvested plant parts of select annual crops

\begin{tabular}{|c|c|c|c|c|}
\hline \multirow[b]{2}{*}{ Crop } & \multirow{2}{*}{$\begin{array}{l}\text { Plant part } \\
\text { harvested }\end{array}$} & Phosphorus & Potassium & \multirow[b]{2}{*}{ Source* } \\
\hline & & \multicolumn{2}{|c|}{$\%$ of dry matter } & \\
\hline \multirow[t]{2}{*}{ Winter wheat } & Grain & $0.25-0.49$ & $0.33-0.66$ & van Duivenbooden et al. 1996 \\
\hline & Straw & $0.03-0.08$ & $1.06-1.92$ & van Duivenbooden et al. 1996 \\
\hline \multirow[t]{2}{*}{ Barley } & Grain & $0.34-0.56$ & $0.49-0.61$ & $\begin{array}{l}\text { Arvidsson 1999; Saskatchewan Ministry of } \\
\text { Agriculture } 2012\end{array}$ \\
\hline & Straw & $0.06-0.08$ & $1.51-1.73$ & $\begin{array}{l}\text { Tarkalson et al. 2009; Saskatchewan } \\
\text { Ministry of Agriculture } 2012\end{array}$ \\
\hline \multirow[t]{2}{*}{ Corn } & Grain & $0.21-0.40$ & $0.20-0.53$ & van Duivenbooden et al. 1996 \\
\hline & Whole plant & $0.14-0.21$ & $1.00-1.40$ & Wortmann et al. 2009 \\
\hline Cotton & Seeds, lint & $0.44-0.45$ & $0.90-1.10$ & Halevy 1976; Cassman, Kerby, et al. 1989 \\
\hline Sunflower & Seeds & $0.57-0.87$ & $0.46-0.92$ & $\begin{array}{l}\text { Deibert and Utter 1989; Gholamhoseini et } \\
\text { al. } 2013\end{array}$ \\
\hline Tomatoes & Fruit & $0.025-0.035 t$ & $0.20-0.30 \dagger$ & $\begin{array}{l}\text { Christou et al. 1999; de C. Carmello and Anti } \\
\text { 2006; Hartz and Hanson } 2009\end{array}$ \\
\hline
\end{tabular}

* Values for these and other crops can also be found online in databases by the Natural Resources Conservation Service (plants.usda.gov/ $\mathrm{npk} / \mathrm{main}$ ) and the International Plant Nutrition Institute (ipni.net/app/calculator/home).

† Concentrations in \% of fresh fruit.

TABLE 3. Estimated phosphorus (as $\mathrm{P}_{2} \mathrm{O}_{5}$ ) and potassium (as $\mathrm{K}_{2} \mathrm{O}$ ) removed from field with harvested crops based on average yields in California

\begin{tabular}{|c|c|c|c|c|}
\hline \multirow[b]{2}{*}{ Crop } & \multirow{2}{*}{$\begin{array}{l}\text { Plant part } \\
\text { harvested }\end{array}$} & \multirow[b]{2}{*}{ Average yield* } & \multicolumn{2}{|c|}{ Total removed $\dagger$} \\
\hline & & & Ib $\mathrm{P}_{2} \mathrm{O}_{5} /$ acre & lb $\mathrm{K}_{2} \mathrm{O} / \mathrm{acre}$ \\
\hline \multirow[t]{2}{*}{ Winter wheat } & Grain & 2.30 ton/acre & $22-44$ & $15-31$ \\
\hline & Straw & 2.30 ton/acre $\neq$ & $3-7$ & $51-93$ \\
\hline \multirow[t]{2}{*}{ Barley } & Grain & 1.49 ton/acre & $20-32$ & $15-19$ \\
\hline & Straw & 1.49 ton/acre $\neq$ & $4-5$ & $48-54$ \\
\hline \multirow[t]{2}{*}{ Corn } & Grain & 4.95 ton/acre & $40-77$ & $20-54$ \\
\hline & Silage & 26.23 ton/acre & $50-76$ & $189-264$ \\
\hline Cotton & Seed, lint & 1,436 lb lint/acre & $41-42 \S$ & $44-54 \S$ \\
\hline Sunflower & Seeds & 1,233 lb/acre & $14-21$ & $6-12$ \\
\hline Tomatoes & Fruit & 41.41 ton/acre & $47-66$ & $200-300$ \\
\hline
\end{tabular}

* Average yield since 2000 in California, based on USDA data (quickstats.nass.usda.gov/).

† The concentrations reported in table 2 were used for the calculations.

₹ Assuming a harvest index (grain yield divided by total aboveground biomass) of 0.5 .

$\S$ Assuming a gin turnout of $35 \%$ (amount of lint in percentage of seed cotton; Fritschi et al. 2003). 
single strip in a field that is otherwise not fertilized; the application rate could be the amount generally removed with the harvested crop. If the goal is to determine whether the normal annual application rate is adequate, one or several different rates can be applied to strips - for example, 20 pounds $\mathrm{P}_{2} \mathrm{O}_{5}$ per acre or 50 pounds $\mathrm{K}_{2} \mathrm{O}$ per acre more or less than the rest of the field.

When possible, the treatments should be replicated, either by establishing several strips with the same treatment in one field or repeating the trial in several fields. The decision whether to include replicated strips as well as the size of the test strips depends on how readily the results will be accepted. Carrying out a trial is meaningful only if growers feel comfortable enough adjusting their management when the trial shows that the new practices are superior.

\section{Future research}

Research addressing the following issues will help increase the value of soil testing. Current soil tests extract inorganic forms of labile P. Development of tests that can assess the mineralization potential of organic P would greatly improve the value of testing in soils with a high organic matter content and in production systems where mineralization of organic $\mathrm{P}$ amendments, such as animal manures and composts, contribute significantly to the plant-available P pool.

Standard soil $\mathrm{K}$ tests are not accurate predictors of fertilizer $\mathrm{K}$ availability in K-fixing soils. Much progress has been made recently identifying K-fixing soils in California. A soil test that can accurately and reliably determine the $\mathrm{K}$ fixation potential of a soil, yet is simple enough to be adopted by commercial soil test labs, still needs to be developed. An improved understanding and quantification of the capacity of different crops to access nonlabile $\mathrm{K}$ would further improve the value of soil testing, not just in K-fixing soils.

Under drip irrigation, the wetting pattern and thus the zone where roots have access to nutrients is more limited than under furrow- or flood-irrigated systems. To ensure appropriate interpretation of soil test values in drip-irrigated fields, current critical soil test values may need to be reevaluated. In addition, there is a need to refine nutrient response curves to soil test values to ensure appropriate application rates.
Test procedures and resulting values among commercial labs may differ, making it difficult for growers to compare the results with published critical values. The industry might benefit from routine comparisons of soil test values reported by different commercial labs: the samples would be taken from selected field sites, require sample preparation before analysis and preferably be blind submissions. Such a program might increase standardization of methods and raise awareness of differences among labs.

Soils differ in their capacity to supply nutrients to crops. Despite its limitations, soil testing is a cost-effective way to assess nutrient availability for specific fields. With the information provided in this article, growers and crop advisers can use soil testing for fertilization decisions that result in efficient and sustainable use of fertilizers. CA

D. Geisseler is UC Cooperative Extension Nutrient Management Specialist in the Department of Land, Air and Water Resources at UC Davis and G. Miyao is UC Cooperative Extension Farm Advisor in Sacramento, Solano and Yolo counties.

\section{References}

Alfaro MA, Jarvis SC, Gregory PJ. 2004. Factors affecting potassium leaching in different soils. Soil Use Manage 20(2):182-9.

Allen ER, Johnson GV, Unmh LG. 1994. Current approaches to soil testing methods: Problems and solutions. In: Havlin JL, Jacobsen JS (eds.). Soil Testing: Prospects for Improving Nutrient Recommendations. SSSA Special Publication No. 40. Madison, WI: SSSA. p 203-20. Arvidsson J. 1999. Nutrient uptake and growth of barley as affected by soil compaction. Plant Soil 208(1):9-19. Beegle D. 2005. Assessing soil phosphorus for crop production by soil testing. In: Sims JT, Sharpley AN (ed.). Soil Testing and Plant Analysis. Madison, WI: ASA, CSSA, SSSA. p 123-43.

Brandon DM, Mikkelsen DS. 1979. Phosphorus transformations in alternately flooded California soils: I. Cause of plant phosphorus deficiency in rice rotation crops and correctional methods. Soil Sci Soc Am J 43(5):989-94.

Bray RH, Kurtz LT. 1945. Determination of total, organic, and available forms of phosphorus in soils. Soil Sci 59(1):39-45.

Brock EH, Ketterings QM, Kleinman PJA. 2007. Phosphorus leaching through intact soil cores as influenced by type and duration of manure application. Nutr Cycl Agroecosys 77(3):269-81.

Burt R, Mays MD, Benham EC, Wilson MA. 2002. Phosphorus characterization and correlation with properties of selected benchmark soils of the United States. Commun Soil Sci Plant Anal 33(1-2):117-41.
Carrijo OA, Hochmuth G. 2000. Tomato responses to preplant incorporated or fertigated phosphorus on soils varying in Mehlich-1 extractable phosphorus. HortScience 35(1):67-72.

Cassman KG, Bryant DC, Roberts BA. 1990. Comparison of soil test methods for predicting cotton response to soil and fertilizer potassium on potassium-fixing soils. Commun Soil Sci Plant Anal 21(13-16):1727-43.

Cassman KG, Kerby TA, Roberts BA, et al. 1989. Differential response of two cotton cultivars to fertilizer and soil potassium. Agron J 81(6):870-6.

Cassman KG, Roberts BA, Kerby TA, et al. 1989. Soil potassium balance and cumulative cotton response to annual potassium additions on a vermiculitic soil. Soil Sci Soc Am J 53(3):805-12.

Childs FD, Jencks EM. 1967. Effect of time and depth of sampling upon soil test results. Agron J 59(6):537-40.

Christou M, Dumas Y, Dimirkou A, Vassiliou Z. 1999. Nutrient uptake by processing tomato in Greece. Acta Hortic 487:219-23

Condron LM, Turner BL, Cade-Menun BJ. 2005. Chemistry and dynamics of soil organic phosphorus. In: Sims JT, Sharpley AN (ed.). Soil Testing and Plant Analysis. Madison, WI: ASA, CSSA, SSSA. p 87-121.

Cox FR. 1994. Current phosphorus availability indices: Characteristics and shortcomings. In: Havlin JL, Jacobsen JS (eds.). Soil Testing: Prospects for Improving Nutrient Recommendations. SSSA Special Publication No. 40. Madison WI: SSSA. p 101-13.
[CPHA] California Plant Health Association. 2002. Western Fertilizer Handbook (9th ed.). Danville, IL: Interstate Publishers, Inc. p 356.

Carmello QA de C, Anti GR. 2006. Accumulation of nutrients and growth of processing tomato. Acta Hortic 724:85-90.

Deibert EJ, Utter RA. 1989. Sunflower growth and nutrient uptake: Response to tillage system, hybrid maturity and weed control method. Soil Sci Soc Am J 53(1):133-8. Ebeling AM, Bundy LG, Kittell AW, Ebeling DD. 2008. Evaluating the Bray P1 test on alkaline, calcareous soils. Soil Sci Soc Am J 72(4):985-91.

Fixen PE, Grove JH. 1990. Testing soils for phosphorus. In Westerman RL (ed.). Soil Testing and Plant Analysis. Madison, WI: SSSA. p 141-80.

Follett RH, Westfall DG, Croissant RL. 1987. Soil test recommendation comparison study. J Agron Educ 16(2):73-6.

Fortune S, Lu J, Addiscott TM, Brookes PC. 2005. Assessment of phosphorus leaching losses from arable land. Plant Soil 269(1-2):99-108.

Fritschi FB, Roberts BA, Travis RL, et al. 2003. Response of irrigated Acala and Pima cotton to nitrogen fertilization: Growth, dry matter partitioning, and yield. Agron J 95(1):133-46.

Gahoonia TS, Nielsen NE. 2004. Root traits as tools for creating phosphorus efficient crop varieties. Plant Soil 260(1-2):47-57. 
Gavlak R, Horneck D, Miller RO. 2005. Soil, Plant and Water Reference Methods for the Western Region. www. naptprogram.org/files/napt/western-states-methodmanual-2005.pdf (accessed Aug. 24, 2015).

Gholamhoseini M, Ghalavand A, Dolatabadian A, et al. 2013. Effects of arbuscular mycorrhizal inoculation on growth, yield, nutrient uptake and irrigation water productivity of sunflowers grown under drought stress. Agr Water Manage 117:106-14.

Haby VA, Russelle MP, Skogley EO. 1990. Testing soils for potassium, calcium and magnesium. In: Westerman RL (ed.). Soil Testing and Plant Analysis. Madison, WI: SSSA. p 181-227.

Halevy J. 1976. Growth rate and nutrient uptake of two cotton cultivars grown under irrigation. Agron 68(5):701-5.

Hancock J. 1992. Extension education: Conducting effec tive agricultural demonstrations. University of Kentucky Cooperative Extension Service. Publication ID-111. www2.ca.uky.edu/agc/pubs/id/id111/id111.pdf (accessed Aug. 24, 2015)

Hartz T. 2008. Efficient fertigation management for dripirrigated processing tomatoes. UCCE Vegetable Notes Fresno, Tulare and Kings Counties 4, 2-3. http://cetulare. ucanr.edu/newsletters/Negetable_Notes_Newsletter30251.pdf (accessed Aug. 25, 2015).

Hartz TK, Giannini C, Miller RO, Miyao EM. 2002. Estimating soil potassium availability for processing tomato production. Commun Soil Sci Plant Anal 33(9-10):1389-400. Hartz TK, Hanson B. 2009. Drip Irrigation and Fertigation Management of Processing Tomato. UC Vegetable Research and Information Center. http://vric.ucdavis. edu/pdf/TOMATO/tomato_drip irrigation and fertigation mgmt of processing tomato 2009 05.pdf (accessed Aug 25, 2015).

Hartz TK, Johnstone PR. 2006. Relationship between soil phosphorus availability and phosphorus loss potential in runoff and drainage. Commun Soil Sci Plant Anal 37(11-12):1525-36.

Hartz TK, Johnstone PR, Francis DM, Miyao EM. 2005. Processing tomato yield and fruit quality improved with potassium fertigation. HortScience 40(6):1862-7.

Hawkesford M, Horst W, Kickey T, et al. 2012. Functions of macronutrients. In: Marschner P (ed.). Marschner's Mineral Nutrition of Higher Plants. London, UK: Academic Press. p $135-90$

Hicks DR, van den Heuvel RM, Fore ZQ. 1997. Analysis and practical use of information from on-farm strip trials. Better Crops 81(3):18-21.

Jacobsen JS, Lorbeer SH, Schaff BE, Jones CA. 2002. Variation in soil fertility test results from selected northern Great Plains laboratories. Commun Soil Sci Plant Anal 33(3-4):303-19.

James DW, Wells KL. 1990. Soil sample collection and handling: Technique based on source and degree of field variability. In: Westerman RL (ed.). Soil Testing and Plant Analysis. Madison, WI: SSSA. p 25-44.

Jenny H, Adams F, Arnon DI, et al. 1946. Exploring the soils of California. In: Hutchison CB (ed.). California Agriculture. Berkeley and Los Angeles: UC Press. p 317-93.

John MK, van Ryswyk AL, Mason JL. 1967. Effect of soil order, $\mathrm{pH}$, texture and organic matter on the correlation between phosphorus in alfalfa and soil-test values. Can Soil Sci 47(3):157-61.

Johnstone PR, Hartz TK, Cahn MD, Johnstone MR. 2005 Lettuce response to phosphorus fertilization in high phosphorus soils. HortScience 40(5):1499-503.

Jones JB, Case VW. 1990. Sampling, handling, and analyz ing plant tissue samples. In: Westerman RL (ed.). Soil Test ing and Plant Analysis. Madison, WI: SSSA. p 389-427.

Khan SA, Mulvaney RL, Ellsworth TR. 2013. The potassium paradox: Implications for soil fertility, crop production and human health. Renew Agr Food Syst 29(1):3-27.
Kuhlmann H, Barraclough PB. 1987. Comparison between the seminal and nodal root systems of winter wheat in their activity for $\mathrm{N}$ and $\mathrm{K}$ uptake. Z Pflanz Bodenkunde 150(1):24-30.

Kuhlmann H, Wehrmann L. 1984. Prüfung verschiedener Methoden der Bodenanalyse auf ihre Eignung zur Ermittlung des K-Düngerbedarfs auf Lößböden. Z Pflanz Bodenkunde 147(3):334-48.

Lazcano C, Wade J, Horwath WR, Burger M. 2015. Assessment of pre-plant NPK in subsurface drip irrigated tomatoes. Calif Agr 69(4):222-9.

Mallarino AP. 1995. Evaluation of excess soil phosphorus supply for corn by the ear-leaf test. Agron J 87(4):687-91. Mallarino AP, Higashi SL. 2009. Assessment of potassium supply for corn by analysis of plant parts. Soil Sci Soc Am J 73(6):2177-83

McDowell R, Sharpley A, Brookes P, Poulton P. 2001. Relationship between soil test phosphorus and phosphorus release to solution. Soil Sci 166(2):137-49.

Mikkelsen DS. 1955. Cotton phosphate fertilization: New soil test provides reliable and easily applied diagnostic guide to quantity of available phosphate. Calif Agr $9(1): 7-15$.

Miller R, Weir B, Vargas R, et al. 1996. Cotton Potassium Fertility Guidelines for the San Joaquin Valley of Califor nia. UC ANR Publication 21562

Munson RD, Nelson WL. 1990. Principles and practices in plant analysis. In: Westerman RL (ed.). Soil Testing and Plant Analysis. Madison, WI: SSSA. p 359-87.

Öborn I, Andrist-Range Y, Askekaard M, et al. 2005. Critical aspects of potassium management in agricultural systems. Soil Use Manage 21(Suppl. 1):102-12.

Oehl F, Oberson A, Sinaj S, Frossard E. 2001. Organic phosphorus mineralization studies using isotopic dilution techniques. Soil Sci Soc Am J 65(3):780-7.

Olsen SR, Cole CV, Watanabe FS, Dean LA. 1954. Estimation of Available Phosphorus in Soils by Extraction with Sodium Bicarbonate. USDA Circular 939. Washington DC US Government Printing Office. p 19.

Palacios-Diaz MP, Mendoza-Grimon V, Fernandez-Vera $J R$, et al. 2009. Subsurface drip irrigation and reclaimed water quality effects on phosphorus and salinity distribution and forage production. Agr Water Manage 96(11):1659-66.

Pennock D, Yates T, Braidek J. 2008. Soil sampling designs. In: Carter MR, Gregorich EG (eds.). Soil Sampling and Methods of Analysis. Boca Raton, FL: CRC Press. p 3-16.

Pettygrove GS, Southard RJ. 2003. Can We Predict K Fixation in the San Joaquin Valley from Soil Texture and Mineralogy? FREP Final Report. www.cdfa.ca.gov/is/docs/ Pettygrove-00.pdf (accessed Aug. 25, 2015).

Pierzynski GM. 1991. The chemistry and mineralogy of phosphorus in excessively fertilized soils. Crit Rev Environ Sci Technol 21(3-4):265-95.

Pierzynski GM, McDowell RW, Sims JT. 2005. Chemistry, cycling, and potential movement of inorganic phosphorus in soils. In: Sims JT, Sharpley AN (eds.). Soil Testing and Plant Analysis. Madison, WI: ASA, CSSA, SSSA. p 53-86.

Pratt PF, Lippert RM. 1986. Residual available phosphorus in soils. Calif Agr 40(3):21-2.

Rees GL, Pettygrove GS, Southard RJ. 2013. Estimating plant-available potassium in potassium-fixing soils. Commun Soil Sci Plant Anal 44(1-4):741-8.

Reisenauer HM, Quick J, Voss RE. 1976. Soil test interpretive guides. In: Reisenauer HM (ed.). Soil and Plant-Tissue Testing in California. University of California Cooperative Extension Bulletin 1879. p. 38-40.

Rengel Z, Damon PM. 2008. Crops and genotypes diffe in efficiency of potassium uptake and use. Physiol Plantarum 133(4):624-36.

Richardson AE, Lynch JP, Ryan PR, et al. 2011. Plant and microbial strategies to improve the phosphorus efficiency of agriculture. Plant Soil 349(1-2):121-56.
Römheld V, Kirkby EA. 2010. Research on potassium in agriculture: Needs and prospects. Plant Soil 335(12):155-80.

Sah RN, Mikkelsen DS. 1986. Sorption and bioavailability of phosphorus during the drainage period of floodeddrained soils. Plant Soil 92(2):265-78.

Samal D, Kovar JL, Steingrobe B, et al. 2010. Potassium uptake efficiency and dynamics in the rhizosphere of maize (Zea mays L.), wheat (Triticum aestivum L.), and sugar beet (Beta vulgaris L.) evaluated with a mechanistic model. Plant Soil 332(1-2):105-21.

Saskatchewan Ministry of Agriculture. 2012. Potassium Fertilization in Crop Production. www.saskatchewan.ca/ business/agriculture-natural-resources-and-industry/ agribusiness-farmers-and-ranchers/crops-and-irrigation/ soils-fertility-and-nutrients/potassium-fertilization-incrop-production (accessed Aug. 25, 2015)

Schoenau JJ, O'Halloran IP. 2008. Sodium bicarbonateextractable phosphorus. In: Carter MR, Gregorich EG (eds.). Soil Sampling and Methods of Analysis. Boca Raton, FL: CRC Press. p 93-8.

Sharpley AN. 1985. Phosphorus cycling in unfertilized and fertilized agricultural soils. Soil Sci Soc Am J 49(4):905-11.

Shaver TM. 2014. Sunflower. In: Shaver TM (ed.). Nutrient Management for Agronomic Crops in Nebraska. University of Nebraska Extension Circular 155. p. 127-130. http:// extensionpubs.unl.edu/publication/9000016363764/ nutrient-management-for-agronomic-crops-in-nebraska. Sharpley A, Foy B, Withers P. 2000. Practical and innovative measures for the control of agricultural phosphorus losses to water: An overview. J Environ Qual 29(1):1-9.

Smyth TJ, Sanchez PA. 1982. Phosphate rock and superphosphate combinations for soybeans in a Cerrado Oxisol. Agron J 74(4):730-5.

Steffens D, Leppin T, Luschin-Ebengreuth N, et al. 2010. Organic soil phosphorus considerably contributes to plant nutrition but is neglected by routine soil-testing methods. J Plant Nutr Soil Sci 173(5):765-71.

Stevenson FJ, Cole MA. 1999. Cycles of Soil. New York, NY: John Wiley.

Tarkalson DD, Brown B, Kok H, Bjorneberg DL. 2009. Irrigated small-grain residue management effects on soil chemical and physical properties and nutrient cycling. Soil Sci 174(3):303-11.

van Duivenbooden N, de Wit CT, van Keulen H. 1996. Nitrogen, phosphorus and potassium relations in five major cereals reviewed in respect to fertilizer recommendations using simulation modeling. Fert Res 44(1):37-49.

Wang HY, Shen QH, Zhou JM, et al. 2011. Plants use alternative strategies to utilize nonexchangeable potassium in minerals. Plant Soil 343(1-2):209-20.

Weir BL, Kerby TA, Hake KD, et al. 1996. Cotton fertility. In: Hake SJ, Kerby TA, Hake KD (eds.). Cotton Production Manual. UC Division of Agriculture and Natural Resources. Publication 3352. p 210-27.

Westfall DG, Whitney DA, Brandon DM. 1990. Plant analysis as an aid in fertilizing small grains. In: Westerman RL (ed.). Phosphorus: Agriculture and the Environment. Madison, Wl: SSSA. p 495-519.

White PJ. 2013. Improving potassium acquisition and utilisation by crop plants. J Plant Nutr Soil Sci 176(3):305-16. Wortmann CS, Dobermann AR, Ferguson RB, et al. 2009 High-yielding corn response to applied phosphorus, potassium, and sulfur in Nebraska. Agron J 101(3):546-55. Wulff F, Schulz V, Jungk A, Claassen N. 1998. Potassium fertilization on sandy soils in relation to soil test, crop yield and K-leaching. Z Pflanz Bodenkunde 161(5):591-9. 